would justify publication. Progress in our understanding of the geological make-up of Antarctica ensures that this is no longer so. Antarctic geologists accept the need to place their findings in a broader context if our understanding of this part of the world is to advance. This volume does just that, reflecting the Symposium's two main themes, tectonic evolution of the the Antarctic crust, and palaeoenvironmental evolution of Antarctica since the Mesozoic.

The first theme takes up some three-quarters of the volume, in five sections. The first 20papers concern development of the Antarctic craton, most involving detailed evidence from particular regions. The next 17 papers cover topics on crustal development of the Transantarctic Mountains; for example Stump and others propose that the Nimrod and Beardmore orogenies are the same, and Rowell and Rees give a detailed note on the Shackleton limestone. Crustal development of the Weddell Sea - Ross Sea region forms the third section, covering seismic, palaeomagnetic, crustal extension, geochemical and other studies. The largest group, of 33 papers, covers virtually all aspects of Antarctica's Pacific margin. The final section of 10 papers covers aspects of the breakup of Gondwanaland. The second theme includes 17 papers on the evolution of Cenozoic palaeoenvironments, many dealing with palaeontology or glaciology.

No volume of this nature can be expected to show uniform quality. Time will determine which of the contributions prove most significant. Contributors from 19 countries reflect the growing interest in Antarctica by an ever-increasing number of nations: the bulk of research is still being done by Australia, Britain, New Zealand and USA, though increasingly significant contributions are being made by Argentina, Brazil, Chile, Poland and South Africa. Topics and regions not fully represented hereinclude geophysical investigations of Antarctic shelves and studies on the Ellsworth Mountains and Marie Byrd Land. But the editors have assembled a very significant collection of papers on the geological evolution of Antarctica: the volume will become an essential work to which all interested in Antarctic geology will frequently turn.

It is a pity that over three years have passed before these proceedings appeared in print. The editors may be congratulated, however, on achieving a volume with internal consistency without enforcing a stereotyped format on the authors. Diagrams and photographs are generally well reproduced and there are few typographic errors. Spot checks failed to fault the full and useful index. This is an excellent volume, highly recommended to all, institutions and individuals alike, who have interest in the geology of the Antarctic or related regions. (C. P. Hughes, Robinson College, University of Cambridge, Cambridge CB3 9AN).

\section{THE FUTURE OF ANTARCTICA}

ANTARCTICA: PRIVATE PROPERTY OR PUBLIC HERITAGE?. Suter, K. 1991. London, Zed Books. 211 p, illustrated, soft cover. ISBN 0862328470 . $£ 9.95$. Aust $\$ 15.00$.

My shelves are filling with rows of small books that advise the world, and the Antarctic Treaty nations in particular, on what they should do about Antarctica. Much of the advice is insubstantial; the Treaty nations rightly view it with suspicion. Keep Antarctica pristine? It hasn't been pristine for years. Make it a continent for science? Scientists are part of its trouble - I'd as soon hand it over to lawyers. Make it an international world park? There is no such thing, and Antarctica is no place for trying one out. Let the United Nations run it? Now that really is fighting talk.

This, mercifully, is a responsible book, written by an international lawyer who has done his homework and tries to be practical. Sketching the background, outlining the Treaty and its works, putting the whole into a context of international law, it sets the scene fairly. Then it draws attention to the deadlock within the Treaty, brought about by loss of consensus, and suggests an interesting way forward. To protect Antarctica, says the author, let us use current awareness of environmental issues (without, one might add, mindlessly banging the green drum). Let us not alienate the Antarctic Consultative parties, for we cannot function without them, and let us not invite in the UN. Let us build on the world park concept, trying to find for it a substantial basis in law - linking it perhaps with a concept of 'public heritage', a variant on the public trust which is gaining growing acceptance throughout the world, and applied at international level.

I do not know if 'public heritage' will prove viable, but this book introduces it simply and sensibly, and merits close reading. If it is not already sold out, I shall recommend it to this year's crop of postgraduate students and see what they make of it. (Bernard Stonehouse, Scott Polar Research Institute, University of Cambridge, Lensfield Road, Cambridge CB2 1ER)

\section{A MAN FOR MOST SEASONS}

A TALENT FOR ADVENTURE. Croft, Andrew. 1991. Hanley Swan, The Self Publishing Association Ltd. 280 p, illustrated, hard cover. ISBN 1854211390 0. 14.95.

Col Andrew Croft DSO OBE has lived through stirring times, making use of every adventure that came his way. This book is packed with good stories from Greenland, India, Svalbard, Lapland, Norway, Corsica, Canada, the North-West Frontier and elsewhere. But Croft is more than an adventurer, and this is far more than a collection of ripping yarns. About half the book is polar: the rest covers a range of activities from 'minding' a budding maharajah to parachuting into wartime France.

Born to a country rectory, educated at Lancing, Stowe, Oxford and Manchester School of Technology, Croft was raised as a middle-class Englishman, neither rich nor poor, destined first for the cotton trade and later for schoolmastering. However, he was one of those astonishing young men, mainly from Oxbridge, who in the 1920s and ' 30 s became competent Arctic explorers, and later distinguished themselves in World War II and in industry, commerce and research. On his first expedition Croft learnt dog-driving and survival techniques from Greenland professionals, and used them well in Greenland. 